\title{
Bushido as allied: The Japanese warrior in the cultural production of Fascist Italy (1940-1943)
}

\author{
Sergio RAIMONDO*1,2, Valentina DE FORTUNA ${ }^{3}$, \& Giulia CECCARELLI ${ }^{3}$ \\ ${ }^{1}$ University of Cassino and South Lazio (Italy) \\ ${ }^{2}$ Area Discipline Orientali Unione Italiana Sport per Tutti (Italy) \\ ${ }^{3}$ Free Lance Translator (Italy) \\ Recepción: 17/10/2017; Aceptación: 19/12/2017; Publicación: 27/12/2017.
}

\begin{abstract}
Introduction: After the signing of the alliance among Japan, Germany and Italy's governments in September 1940, several journals arose in order to spread the Japanese culture among people who knew very little about Italy's new allied. Some documentaries also had the same function. Methods: The numerous textual and iconographical references concerning the Japanese warriors' anthropology published in some Italian magazines during the 1940s have been compared, as well as to the few Italian monographs on the same theme and to some documentaries by Istituto Nazionale Luce, government propaganda organ. This subject has also been compared to the first Italian cultural production, concerning Japan, which dated back to the first decades of the $20^{\text {th }}$ century. Moreover different intellectuals' biographies of those times have been deeply analyzed. Results: Comparing to each other the anthropological references about Japan in the Italian cultural production during the Second World War, we can notice a significant ideological homogeneity. This can be explained through their writers' common sharing of the militaristic, hierarchical and totalitarian doctrine of the Fascist Regime. The Fascist ideology can be summarized in the Bushido concept, as Inazo Nitobe defined it in 1916. This concept was already known in Italy on the early $20^{\text {th }}$ century, far before Fascism. Discussions and conclusions: We can see how Italian perception of the Japanese anthropology on the early $20^{\text {th }}$ century didn't change over time and how its features will reappear in the 40s under the influence of the Italian-Japanese coalition. So, Bushido became the essence of the Japanese military and national identity that Fascist Italy took as example for mass education. Some of these stereotypes will reappear after the war and until recent times in popular culture and in mass perception of Japanese martial arts.

Keywords: Fascist Ideology; Japanese Martial Tradition; Heroism; Loyalty; Martial Arts; Japan.
\end{abstract}

\section{El Bushido como aliado: el guerrero japonés en la producción cultural italiana (1940-1943) \\ Resumen}

Introducción: Tras la firma de la alianza entre Japón, Alemania e Italia en septiembre de 1940, surgieron diversas revistas para difundir la cultura japonesa entre una población que sabía muy poco sobre el nuevo aliado de Italia. Algunos documentales también tuvieron el mismo propósito. Métodos: Se han comparado numerosas fuentes textuales e iconográficas relacionadas con la antropología de los guerreros japoneses, publicadas en algunas revistas italianas durante la década de 1940, así como algunas monografías italianas sobre el mismo tema y algunos documentales del Istituto Nazionale Luce, órgano de propaganda del gobierno. Este tema también se ha comparado con la primera producción cultural italiana referente a Japón, que se remonta a las primeras décadas del siglo XX. Además, se han analizado en profundidad las biografías de diferentes intelectuales de aquel periodo. Resultados: Comparando las referencias antropológicas sobre Japón en la producción cultural italiana durante la Segunda Guerra Mundial, podemos observar una significativa homogeneidad ideológica. Esto se explica porque los autores compartían la doctrina militarista, jerárquica y totalitaria propia del régimen fascista. La ideología fascista se puede resumir en el concepto Bushido,

\section{O bushido como aliado: o guerreiro japonês na produção cultural italiana (1940-1943)}

\section{Resumo}

Introdução: Com a aliança estabelecida entre o Japão, a Alemanha e a Itália, em setembro de 1940, surgiram diversas revistas a difundir a cultura japonesa, por entre uma população que sabia muito pouco sobre os novos aliados de Itália. Alguns documentários também tiveram o mesmo propósito. Métodos: Compararam-se numerosas fontes textuais e iconográficas relacionadas com a antropologia dos guerreiros japoneses, publicadas em algumas revistas italianas durante a década de 1940, assim como algumas monografias italianas sobre o mesmo tema, e alguns documentários do "Istituto Nazionale Luce", órgão de propaganda do governo. Este tema também se comparou com a primeira produção cultural italiana referente ao Japão, que remonta às primeiras décadas do século XX. Por outro lado, analisou-se, em profundidade, as biografias de diferentes intelectuais desse período. Resultados: Comparando as referências antropológicas sobre o Japão na produção cultural italiana durante a Segunda Guerra Mundial, podemos observar uma significativa homogeneidade ideológica. Isto explica-se porque os autores compartilharam a doutrina militarista, hierárquica e totalitária própria do regime fascista. A ideologia fascista pode-se resumir no conceito de Bushido,

${ }^{*}$ E-mail: sergio.raimondo@uisp.it 
tal y como lo definió Inazo Nitobe en 1916. Este concepto ya se conocía en Italia a principios del siglo XX, mucho antes del fascismo. Discusiones y conclusiones: Podemos observar cómo la percepción italiana de la antropología japonesa a principios del siglo XX no cambió con el tiempo y cómo sus características volverían a aparecer en los años 40 por la influencia de la coalición italo-japonesa. Así, el Bushido se convirtió en la esencia de la identidad militar y nacional japonesa que la Italia Fascista tomó como ejemplo para la educación de masas. Algunos de estos estereotipos volverían a aparecer tras la guerra e incluso en tiempos recientes en la cultura y percepción popular de las artes marciales japonesas.

Palabras clave: Ideología fascista; tradición marcial japonesa; heroísmo; lealtad; artes marciales; Japón. tal como o definiu Inazo Nitobe, em 1916. Este conceito já era conhecido em Itália no início do século XX, muito antes do fascismo. Discussões e conclusões: Podemos observar como a percepção italiana da antropologia japonesa, no início do século $\mathrm{XX}$, não mudou com o tempo e como as suas características voltaram a aparecer nos anos 40 por influência da coligação italiano-japonesa. Assim, o Bushido se converteu na essência da identidade militar e nacional japonesa, que a Itália fascista tomou como exemplo para a educação das massas. Alguns destes estereótipos voltariam a surgir com a guerra, e nos tempos recentes, na cultura e percepção popular das artes marciais japonesas.

Palavras-chave: Ideologia fascista; tradição marcial japonesa; heroísmo; lealdade; artes marciais; Japão.

\section{Introduction: Italy and Japan's ideology and diplomacy towards Second World War}

The 27th of September 1940 the totalitarian governments of Italy, Germany and Japan signed an alliance known as "The Tripartite Pact". With this agreement the three countries recognized each other's areas of influence in Asia and Europe (Avarna di Gualtieri \& Società Amici del Giappone, 1940).

The Second World War had already begun in 1939 with Germany invading Poland; in June 1940 Italy declared war to the Anglo-French Alliance, and after one year they signed the alliance, Japan would have entered war attacking Pearl Harbor American base in December 1941.

Japan would have also stopped war with its unconditional surrender on the 15th August 1945, official date for the end of conflicts after Germany surrendered to the Red Army in June 1945 and Italy's Fascist government collapsed two years before.

Italy's Fascist government decided to sign the Tripartite Pact at a time when its action was not so incisive; as a matter of fact Italy didn't have a political autonomy in Far East (Ferretti, 1986, 1995) and moreover Italian diplomats didn't take part to negotiations preceding the Pact but they just signed the text that the Nazi Foreign Minister, Joachim von Ribbentrop, personally brought to Rome in September 1940.

Anyway, apart from this episode when Mussolini's government aligned itself with the Nazi policy in Far East, in previous years the relationship between Fascist Italy and Mikado, the Japanese Empire, had always been based on a mutual particular attraction that might have led to a formal alliance completely detached from Third Reich goals and guidelines (Mussolini, 1935).

This study purpose is to deepen those cultural aspects and habits that awakened a mutual interest between intellectuals, politicians and high officials of both Italy and Japan. We refer to the upper-middle class interest since the working-class didn't have much acknowledgment of such a distant and different country.

Therefore, we will be able to demonstrate that this mutual interest wasn't just linked to the political circumstances of the 30s, but it had its roots in a way of thinking that both states began to share in former years, laying the foundations for a legacy that would have been re-discovered in the second half of the $20^{\text {th }}$ century.

Italian historiography, which inquired into the relationship between Italy and Japan - not in recent times -, just inquired the diplomatic policy field (Ferretti, 1986, 1995); so, from this inquiry emerged that Italy and Germany's actions towards Japan were mostly strategical, but the cultural independent friendship between Italy and Japan was not studied in deep.

This study aims to date back to those Japanese features in which Italian culture of the Fascist Era recognized itself. This quest is particularly about the cultural production, regarding this field, which appeared in Italy during the years of co-belligerence with Japan, but it will outline the fact that the already mentioned Italian identification with the Japanese country preceded the Tripartite Pact period. 
Particularly important in Italy was the use of the "Bushido" idea - meaning "the path of the knight" or "the path of the warrior", and of the included idea of "Yamato-damashii" - meaning "The soul of Old Japan". At the same time, in the second half of the 30's, in Japan some war supporters organized a socio-cultural movement, which celebrated an alleged Japanese Spirit with a strong inclination for war (Beasley, 1969; Caroli \& Gatti, 2004; Tipton, 2011).

Fascist sympathetic inclination towards Japan decisively emerged in this same period - after a particular attraction towards China until 1936 - thanks to the initiative of some high-level intellectuals and diplomats we will talk about later. Therefore, contrary to the mind-set Italy had until 1935, Fascist Italy stopped considering Japan as the main exponent of a never faded "Yellow Peril" (Degli Uberti, 1933; Quadrivio, 1935; Zischka, 1935).

Therefore, the cultural convergence began in 1936 with the philosopher Giovanni Gentile (1875-1944) who was, above all the positions held in fascist cultural institutions, CEO of the IsMEO (Istituto Italiano per il Medio ed Estremo Oriente or Italian Institute for Middle and Far East) that he also founded in 1933 (Ferretti, 1986; Giro, 1986).

Different famous professors were sent on a mission in Japan: first of all Giuseppe Tucci (1894-1984), co-founder and Secretary of the IsMEO and the most influential Italian Orientalist. Second on the list, there was Carlo Formichi (1871-1943), another Orientalist who, in 1942, would have edited a volume about the Italian - Japanese friendship (Formichi, 1942), and last but not least Francesco Severi (1879-1961), a mathematician globally recognized.

During the 30s, political interests of both governments, Italian and Japanese ones had already began to converge on the global chessboard. Nevertheless, this outcome was not so predictable since the Fascist government had shown, at least for the first half of the decade, a strong interest in establishing a connection with Jiăng Jièshí 's China (Fatica, 2014). Jiăng Jièshí (18871975) is better known as Chang Kai-Shek according to the Wade Giles method transcription, which was replaced in the 50s by the Hànyŭ Pīnyīn. Otherwise, other countries like Ethiopia, since the beginning of the $20^{\text {th }}$ century, had always had a good relationship with Japan (Calvitt Clarke, 1999). Nevertheless Japan, also known as "the Land where the sun rises", left Ethiopia to its faith when the Italian Army attacked in October 1935, even though Japanese public opinion was initially against the brutality of the Italian attack. On the other hand, numerous Japanese intellectuals and bureaucrats saw this action, as a healthy shake to the world order so far dominated by AngloAmerican free powers (Hofmann, 2015). The invasion of Ethiopia, that was more violent than a normal colonization (Del Boca, 2007), exposed Italy to be sentenced by the League of Nations, exactly as it had already happened to Japan in 1931 when it invaded Chinese area of Manchuria, also establishing the puppet state of Manchukuo. As a result, Japan left the League of Nations two years later.

The converging imperialistic interests of both countries therefore let to a first formal and important approach, since they both recognized each other's colonies of Ethiopia and Manchuria. Therefore, the Italian Empire in Africa established on 9 May 1936 and including Eritrea and Somalia was thus legitimated for the first time by a great world power.

In November 1937 Italy signed the Anti-Comintern Pact, already signed a year before by both Third Reich and Mikado. In 1938, Italy carried out two diplomatic missions in Japan to strengthen their relationship. The first mission on February 1938, led by Giacomo Paulucci di Calboli Barone Russo (1887-1961), was mostly ideological; otherwise the second mission, which took place between May and June and involved the state of Manchuria, had a more economic purpose and was led by the Senator Ettore Conti di Verampio (1871-1972) - who already was President of Confindustria, the General Confederation of Italian Industries - accompanied by sixteen representatives and experts of main economic bodies (Conti di Verampio, 1946). Conti di Verampio concluded a major economic trade agreement with the Foreign Minister and general Kazushige Ugaki (1868-1956), also signed by Giacinto Auriti, Ambassador in Japan from 1933 to 1939 (Paulucci di Calboli Barone Russo, 1940; The Osaka Mainichi, 1938; Istituto Nazionale Luce, 1938b; Missione del Partito Nazionale Fascista nel Giappone, 1938; Calanca, 2016).

Two years later, between April and June, few months before the signing of the Tripartite Pact, a similar Japanese mission visited Italy. 
In the meantime, the similarities of both countries had become subject of intellectual debates. Apart from the common anticommunist ideology, there was the shared belief of being a superior civilization and therefore legitimized to expand their borders in order to find new raw materials sources and to face overpopulation (Avarna di Gualtieri, 1940). Moreover, Fascism considered the warrior attitude in Japanese tradition as an additional civilization value to emulate. On the contrary, Japan considered Fascism as an interesting complement and completion of its own warrior tradition even though Japan maintained its specific features: for example, Japan continued to have the emperor as national and political chief instead of adopting the Italian and German system of dictators like Mussolini and Hitler to maintain the totalitarianism (Hofmann, 2015).

However, the German-Soviet Non-Aggression Pact signed on August 1939 - which suspended the anti-Comintern Pact until Germany invaded the Soviet Union in June 1941 - brought the Italian-Japanese friendship towards a consolidation of the Tripartite Pact together with Germany and towards a common conduct of war instead of pushing them towards a bilateral agreement.

\section{Bartolomeo Balbi and Shimoi Harukichi cultural mediation}

If we compare how the Japanese culture appears in documentaries of the 30s, which means just before the Second World War, and how it appears in three Italian magazines - Yamato, Civiltà and Sapere - published in war times, we will see a substantial ideological homogeneity coming from a military, hierarchical and totalitarian doctrine Japan shared with Fascist Italy. This ideology can be summed up with the concept of "bushido" as defined in 1899 by Inazo Nitobe (1862-1933) (Nitobe, 1917). Nitobe defined "bushido" as the Path/Code/Ethics of the Knight/Warrior.

The word "bushido" however was not discovered by Fascism; actually it was already known in Italy since 1916, that means before Fascist Era, thanks to Bartolomeo Balbi (1874-1961), an active disseminator of Japanese culture with his own and specific publishing house. On that period Balbi also drove his attention towards translating Japanese narrative and poetry about recent war and martial tradition; later on he would have also used these themes to write critical essays of military subject (Balbi 1916 a, b, c; Sakurai, 1913). Particularly successful and persistent in the future was Balbi's translation from English of a story inspired by 47 Rônin opera (Mitford, 1916) that was published in 1916 after it had been edited by another author in 1908 (Boari, 1908).

Italian people were already sensible to the themes exposed in "47 Rônin" thanks to the already successful drama "Madama Butterfly", written by Giacomo Puccini (1858-1924), libretto by Giuseppe Giacosa (1847-1906) and Luigi Illica (1857-1919). In effect it is important to underline the "loyalty" theme that we can find both in the unlucky hero of Madama Butterfly and in the 47 Rônin. Other important fact is that Puccini wrote the opera with the careful advice of the famous actress Sada Yacco (1871-1946) and of the Japanese ambassador's wife about Japanese habits.

Nevertheless, the Italian drama in its first version, shown in Milan for the first time in

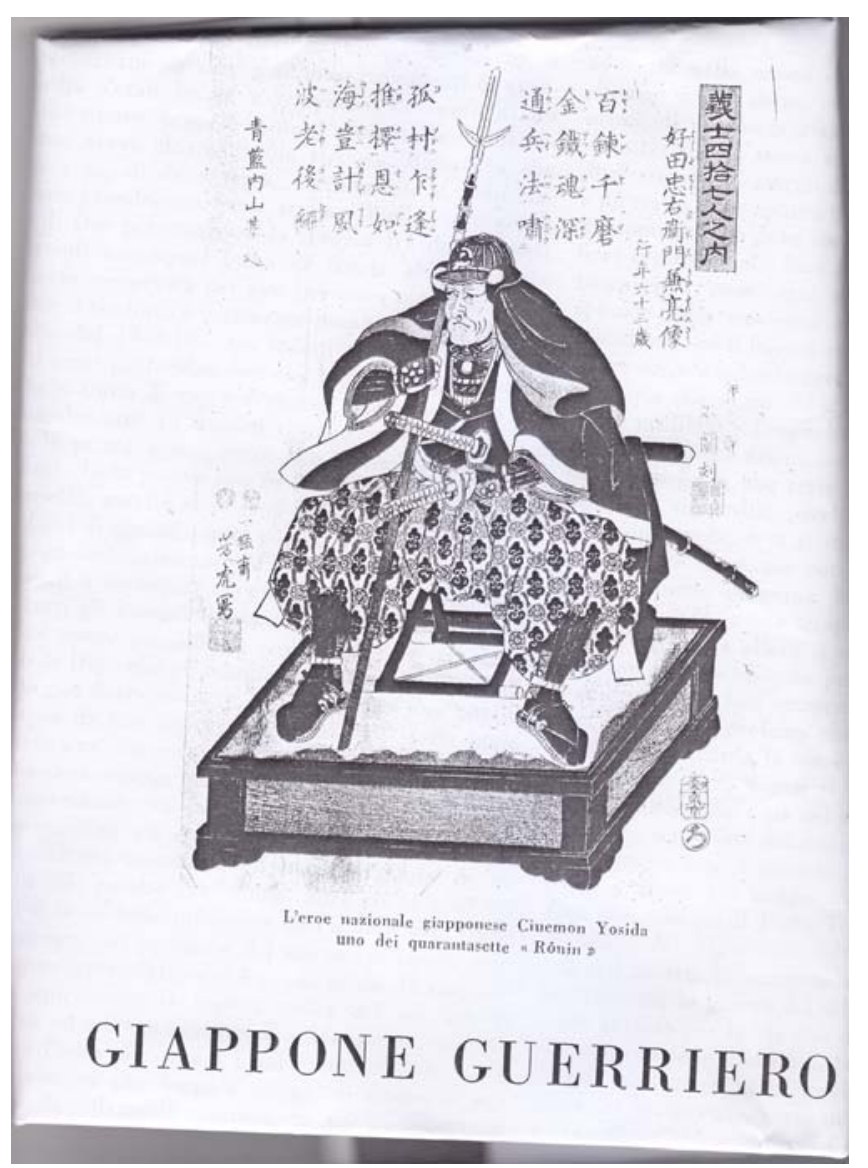

Picture 1. One of 47 Rônin. Source: "Civiltà. Rivista trimestrale dell'Esposizione Universale di Roma", 1942, Jan. 21, III, 12, p. 5. 


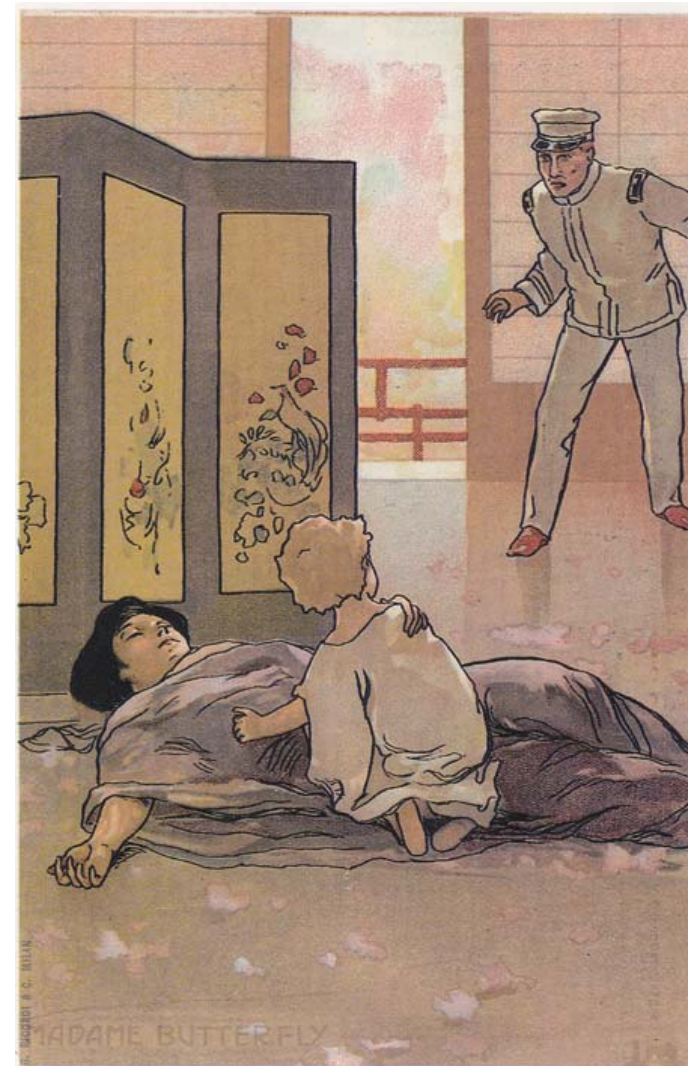

Picture 2. L. Metlicowitz, Butterfly's death, Ricordi, Milano, 1904

1904, was a complete failure. Then, after few revisions, it had a huge success in Brescia the same year, in other Italian theatres and in main European theatres (Illica, Giacosa, \& Puccini, 1904; Centro studi Giacomo Puccini, 2005; Teatro dell'Opera di Roma-Ufficio Stampa, 1990).

Loyalty as symbol of the Japanese spirit was then celebrated by the leader of Fascism, Benito Mussolini (1883-1945), who ordered, in 1928, the delivery in Japan of an ancient porphyry column to celebrate the ritual suicide of young men of the Byakkotai. This last was the White Tiger unit who committed suicide in $19^{\text {th }}$ century to show loyalty to the Shogun power, opposed to the imperial power considered too submissive to Western powers (Martinelli, 2003; Nimura, 2015; Pinguet, 1984). The column - rediscovered in Rome during excavations on Via Nazionale for the project of a new Parliament, then aborted - was enriched with a base and an eagle on the top, both works of the famous artist Duilio Cambellotti (1876-1960). Pompeo Aloisi, diplomat, admiral and secret agent (1875-1949) was the one in charge of the entire operation, from the selection of the right column, to its transportation until the inaugural ceremony in Japan and he would have also told the whole story in detail on Yamato magazine (Aloisi, 1941).

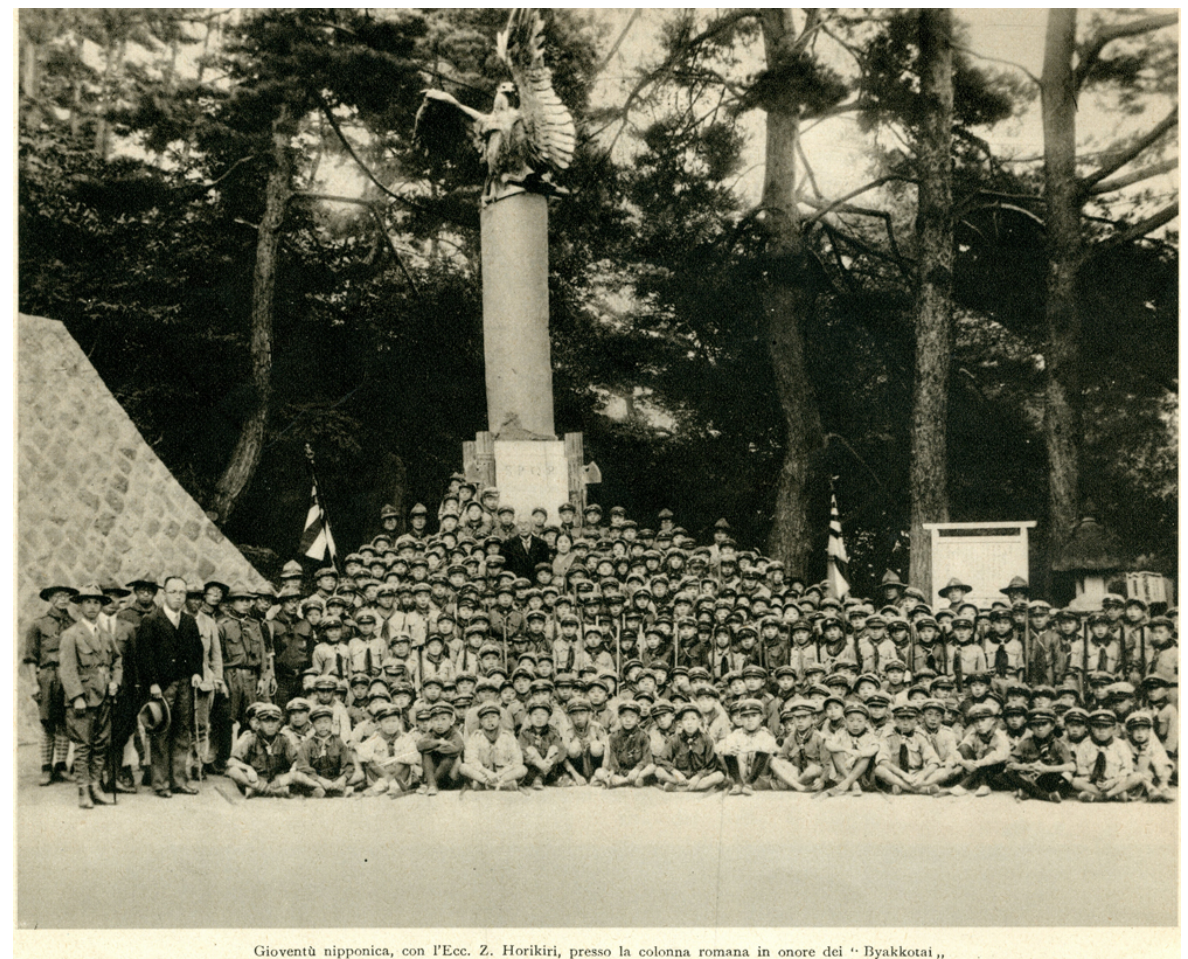

Picture 3. Japanese students and authorities around ancient roman column at Limori hill in Tokyo. Yamato. Mensile italo-giapponese, 1941 May, I, 5, p. 138
Today the column is on the Limori hill in Tokyo, has a commemorative Italian writing and it is still object of pilgrimage. Anyway the one who told Mussolini the story of Byakkotai was Shimoi Harukichi (1883-1954), known in Italy and Japan as literary man but also as soldier since he was part of the Italian assault troops during the Great War (Bernardini Napoletano, 2015; Doi, 2014; Hofman, 2015; Merlino, 2003; Shimoi, 1919).

A meaningful coincidence was the contemporary presence of Balbi and Shimoi as teachers at the Istituto Orientale of Naples in the second half of the 10s (Zagra, 1996), that makes us suppose they influenced each other. This fact would require
further study since also Pietro Silvio Rivetta di Solonghello (1886-1952) taught in the same institute together with Balbi and Shimoi and he is one of those who would have had an important role in spreading Japanese culture throughout Italy after the Tripartite Pact. 


\section{Bushido revealed to Italians}

\subsection{Documentaries}

Starting from 1938 spring, Japanese ideals, seen in a strictly fascist way but mediated by martial arts, which were an expression of Bushido, were introduced to the Italian audience through new mass media. In late April, the newsreel Luce broadcasted a short film showing a judo and kendo performance - meaning "Gentle Way" and "Sword Way" respectively - taking place at the fencing gymnasium of the Foro Mussolini (Mussolini's Forum), today known as Foro Italico. The performers were twelve Japanese students - six for judo and six for kendo - who went to Italy for a cultural visit organized by both Italian and Japanese Foreign Ministers (Istituto Nazionale Luce, 1938a).

In the month of August, the same newsreel broadcasted a 32 minutes film about the already mentioned previous February Fascist mission to Japan. Apart from underlining the fast modernization of the country, the voice-over accompanying the images insisted to highlight the traditional Japanese warlike attitude. This idea, repeatedly stressed throughout the documentary, anticipated some of the themes with which the most important fascist intellectuals - assuming that there were also anti-fascist ones - would have introduced Japanese anthropology to their fellow citizens through periodical publications of the early 40s. After two minutes of images enhancing the neat modernity of Tokyo and the amazing industrial development operated in the country within a few decades, Japanese martial arts, both modern and traditional ones, become absolute protagonists of the story. When the voice-over affirms: "Japanese people had always had, since ancient times, a strong passion for sports", images change from a steelwork to a Japanese flag and a loud drum marking the times with which two groups of dozens of guys, protected by helmet and gloves and armed with the bokken, a heavy wooden sword, battle against each other. The voice-over keeps saying that "fight and fencing in the traditional form are commonly practiced by both young and old people" while images show firstly the performance of expert judokas and kendo practitioners and then a large group of children and youngsters of both sex playing judo.

Few minutes are also dedicated to a sumo fight - a body-to-body fight that literally means "jerking" - and then to images of skiers explained by the voice-over as a great attention to western sports. Anyway, martial arts keep being the centerpiece of the story, in fact the documentary shows other kendo fights, this time performed by adults wearing the usual protective harness and fighting in front of an audience made of soldiers in uniform. Here the voice-over underlines that "also at the military academy body exercises are very important because soldiers must be soldiers both in muscles and heart". Other few minutes are dedicated to a public event where hundreds of athletes practice kendo, "expression of the Japanese military spirit". After the event, the documentary shows a march of soldiers in battle gear. The voice-over comments on this image saying that the Japanese army preserves the patriotic war spirit intact - spirit called yamato-damashii - as already proved throughout the centuries, and that is what makes Italian people and Japanese people alike. Then images change back to manufacturing facilities, cheering crowds, traditional performances, Buddhist temples, clips of rural life and landscapes. After 25 minutes, the documentary shows another gymnastics performance, a female one this time, and the voice-over informs that "also working classes care for physical culture".

Yamato-damashii: in 1938 it was already clear to commentators of the economic-diplomatic mission in Japan which one was the peculiarity they had to underline to define the spirit that identified the Japanese army. Few years later, this same concept would be used in Italian cultural magazines dealing with this subject to represent the entire Japanese society.

The term appeared for the first time in the $11^{\text {th }}$ century in the novel Genji monogatari (Orsi, 2012; Puette, 1983), written by Murasaki Shikibu, (approximately 973 - 1014 or 1025). This novel was one of the masterpieces of Japanese literature, and the term yamato-damashii referred to a virtue typical of those who had received a rigorous traditional culture identified with the Chinese one. Yamato-damashii originally did not push for a nationalist or racist idea, but rather for an opening towards Chinese cultural heights as a vehicle to enhance the Japanese spirit, even though there was already the consciousness of a Japanese distinctive trait. It was only in the Edo period, during the isolation of the country induced by the so-called Pax Tokugawa, that Yamato-damashii

Rev. Artes Marciales Asiát., 12(2), 82-100 2017 
would have been identified with moral values of samurai lifestyle: honor, courage, self-sacrifice and loyalty, all summed up in the word bushido, the Path of the Warrior (Pinguet, 1984).

Then, in modern Japan - quickly industrialized and constitutionalized in the last decades of the $19^{\text {th }}$ and early $20^{\text {th }}$ centuries - the Bushido concept would have been an instrument of affirmation of the nationalistic, militaristic and imperialist doctrine that would have conquered the country especially from the second half of the 20s becoming stronger after a decade (Beasley, 1969; Benesch, 2014; Caroli \& Gatti, 2004; Kanno, 2005; Tipton, 2011). Therefore, we should remember that all this took place after the dissolution of the democratic institutional experiment, in the context of the defeat of the political and trade union forces struggling for a people-oriented society, or even for a socialist one. Nevertheless, it is important to underline that this "invention of tradition" - according to the well-known expression of Eric John Hobsbawn - had already been implemented at the end of the nineteenth century, long before the beginning of totalitarianism. Therefore, it is not an example of fascist attitude typical of Nationalism, but it is part of the Japanese Invention of imperialism seen as an expression of country modernization.

\subsection{The magazines: Sapere}

Let's go back to Italy. In December 1940, the first Italian scientific magazine called "Sapere" (1940) dedicated a monographic number to the distant and almost unknown Asiatic new ally.

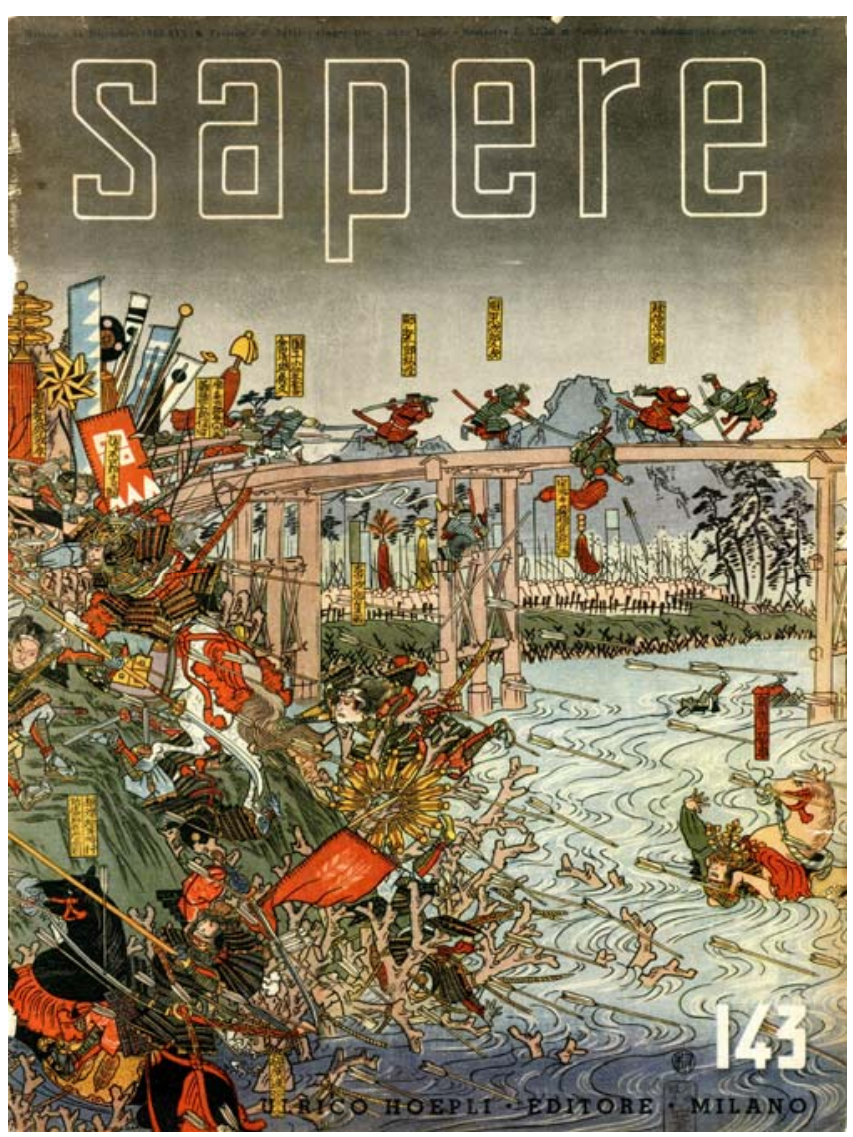

Picture 4. Cover. "Sapere. Quindicinale illustrato di divulgazione delle scienze, della tecnica, delle arti e della cultura generale", 1940, Dec. 15, VI, vol.XII, s.II, p. 23/143, Hoepli, Milano.

With regards to the ideological contents concerning Japanese warrior mentality, the magazine "Sapere" anticipated what the magazine "Yamato" would have analyzed iconographically between 1941 and 1943 . Moreover, in 1942 "Civiltà", the magazine which accompanied the Universal Exhibition in Rome, published two articles about the same issue (Auriti, 1942; Gentile, 1942).

Therefore, in the magazine "Sapere" there were not only all the themes used by fascist ideologists to spread Japanese identity among Italian people, but also the signatures of all those ideologists who were part of this identity. Moreover this was not the first time this magazine dealt with Japanese culture. The headlines significantly said: "ItalianJapanese Friendship" and the article was signed by the ambassador Paolucci di Calboli who also underlined how both Italian and Japanese people considered "spirit over matter" and "economic phenomena only in terms of greatness of the country", anticipating the main themes of the entire magazine. These same themes were deepen in the following articles such as "Il segreto della potenza nipponica. Yamato damashii" (The secret of the Japanese power. Yamato damashii) and "Mistica dell'eroismo giapponese" (Misticism of Japanese heroism), the first one signed with the pen name Nipponicus - still unknown - and the second one written by colonel Moriakira Shimizu (1896-1979), military attaché at the Japanese embassy in Italy. Colonel Shimizu, after directing the propaganda department of Japanese Armed Forces in 1935 as general officer, was then assigned, in 1939, to the Japanese embassy in Italy where he worked until the end of war (Tama Temple, 2017). 
Some passages of the first article are fundamental since they clearly report an idea of the society based on organicism which solved with magical harmony every social conflict according to a perfect moral idealism: "Yamato-damashii is not just in warlike patriotic spirit" since it also includes "the professional, working, scholastic, domestic and social duty. The humblest Japanese worker has constant consciousness of being useful to his own country and to his Emperor, both in war and peace times". Then the article states: "It is not possible to establish material and spiritual boundaries for the Yamato-damashii: therefore amor patrio (patriotism) is an incomplete translation of its meaning; we should also include in its definition: a duty towards every possible field, or better, the intimate and joyful perpetual will to fulfill one's own duties... This way, the Yamato-damashii gives birth to that big harmony which must reign over people and things, which pushes the strong to protect the weak with an affection that is not just towards human people, but also towards every living organism... The Yamato-damashii has no limits since the whole Japanese life is made of it: it is the bond between spirit and matter: spirit in its strongest and highest definition and matter as something sublimated by the Yamato-damashii." Therefore, this vision of the world was clearly linked to an anti-historical spiritualistic idealism, in line with an anti-modern approach adopted by Japan (Benesch, 2014; Tipton, 2011; Vlastos, 1998). This ideological approach would have been the central theme of all the articles with which fascist intellectuals would have presented Japanese identity to Italian people.

In the second article colonel Shimizu reminds us how Japanese traditional culture considered the emperor, the so called Mikado, as the supreme authority, so unreachable that he was revered as a god. Shimizu also explains that the guardians of imperial tradition were the armed forces, faithful to the emperor thanks to the education that every Japanese child absorbed from the same family circle: "Starting from childhood, Japanese lives in a general spiritual atmosphere of heroism and stoicism, so that at the age of reason, he automatically feels the sacrifice as a natural instinct. Family education, school education at every stage, the social conception of life, the life itself, the military service training, the exercises that take place on reality ground, everything contributes to forge the perfect soldier, with a strong body and with an even stronger spirit". Colonel Shimizu also explains that, obviously, the role of women, not just as mothers, was crucial in the perspective of forging, starting from childhood, a soldier who was certainly faithful to his homeland and to his divine commander: "The woman who, in general, is very modest, kind, mild and gentle, always smiling to bring the grace of femininity everywhere, has an incomparably strength. The woman, mother, bride, sister or daughter, belonging to any social class, contributes, with her inimitable art, to create the traditional spirit. Taking care of the house and of the whole family, she gives the man safety and tranquility, so that he is happy and only worried about faithfully executing the emperor's orders". Shimizu also writes about the role of martial arts: "Fencing and giugizu [SIC!] exercises, that military and middle class people never forget to do, contribute to giving a special training which has proved to be essential in war to cope with body-tobody combat and surprise attacks". The other articles kept exalting 1938 Fascist missions in Japan, clarifying how Italy supported Japanese Foreign policy.

\subsection{The magazines: Yamato}

A few months after the Tripartite Pact, in January 1941, the "Yamato" publications began. "Yamato" was an Italian-Japanese monthly published magazine, which was in fact the heart of the association "Friends of Japan" which was founded in 1926 with the first presidency assumed by Paulucci di Calboli, a former member of Ismeo (Istituto Italiano per il Medio ed Estremo Oriente Italian Institute for Middle East and Far East), nominated directly by Mussolini (Calanca, 2016, p. 242). The magazine was in fact entirely dedicated to the spread of Japanese culture to the vast Italian public, little informed about the character of the new allies. It was published regularly by the prestigious "Istituto Geografico De Agostini" (Geographic Institute De Agostini) until August 1943, just after the fall of the Fascist regime on the $25^{\text {th }}$ of July and just before the end of the hostilities between Italy and the Allies, announced on September the 8th. The editorial board of the magazine was composed by Pietro Silvio Rivetta di Solonghello - known under the pseudonym of Toddi, who was also the editorial director - Giuseppe Tucci and Giacinto Auriti, that is to say the board was composed by major experts of those years of Japan and the Far East. 
Rivetta was a well-known journalist and a multilingual writer and, among other things, he also could speak Japanese and Chinese. Since 1910 he worked in Japan on several occasions (Sika \& Verde, 1999), so that in his greeting published in the first issue of the magazine, the Japanese ambassador in Italy Horikiri Zembei (1882-1946) wrote that he was pleased that Rivetta was the director because he was "so popular in our country for his knowledge of our language and his diffusion works." It should also be noted that, several decades before, Rivetta had obtained a teaching post at the Oriental Institute of Naples just in the same period as Balbi and Shimoi also taught there, and this is a coincidence which undoubtedly deserves a scrupulous study.

We have already mentioned the figure of Giuseppe Tucci, an Italian archaeologist, anthropologist and academician whose work is still so studied in universities around the world that many presentations are unnecessary. However, it must be underlined here that the eminent scholar put his authoritative scientific expertise at the service of Fascist foreign policy, so much that he was considered the spokesman for Mussolini in Asia (Garzilli, 2012). Regarding the subject we are discussing here, one of his publications about Japan is a small essay specifically dedicated to bushido (Tucci 1942, 1943) where Professor Tucci reiterated what at the same time constituted the main concept of the Yamato periodical. The volume was also integrated by another short essay entitled Advises to Soldiers About Battle Coalitions, that had already been published in the same magazine and translated by the aforementioned Colonel Moriakira Shimizu, who was also among the members of the magazine itself, though under the name of Simizu, in an Italian version or, better, a fascist version of his name. Giuseppe Tucci though went beyond the bushido's political meaning, even more than the magazine itself, to the point that he translated the term as "soldier's way", an interpretation that could not be found neither in the book by Inazo Nitobe, nor in other sources, including works of other fascist intellectuals.

Giacinto Auriti was most present in the political ground than his three colleagues, having been ambassador of Japan from 1933 to 1940, and he also founded in the Country the Italian Culture Institute (Sika \& Verde, 1999). He was also the author of a compendium of Japanese history and a fine collector of Oriental art (Lanciotti, 1962).

The three editors were assisted by several advisors. As for Italy, the Plenipotentiary Minister in Albania Ottaviano Armando Koch (1888-1979), the aforementioned Pompeo Aloisi, Ambassador Paulucci of Calboli, and then the then president and secretary of the Friends of Japan, Carlo Formichi and Carlo Avarna di Gualtieri (1885-1964). As for Japan, a couple of journalists and some personalities of the Japanese embassy in Italy, including Navy Admiral Toyo Mitunobu (18971944), but especially the military attaché, Colonel Moriakira Shimizu, who was much involved in this project.

“The monthly published magazine 'Yamato' has the purpose of showing and teaching our numerous readers, even of medium culture, the intimate characteristics of Japan ... Many Italian people even ignore that 'Yamato' is the classic, solemn and venerable name of Japan: they will learn to understand the spirit of 'Yamato', through the articles of the few writers who today can help them visually familiarize the treasures of art, natural beauties and the typical customs of the Country our friend." With these words the direction of the new periodical explained its intentions in the first issue printed in January 1941 but its markedly political role was reiterated on the same page by a greeting message written by the Minister of Culture, Alessandro Pavolini (1903-1945): "The new magazine is born in a climate of war that unites the ideals and destinies of the Italian and Japanese people, traditionally friends since the two ancient civilizations resurrected to modern political life and to the will of power. 'Yamato'... also brings his contribution to our strong friendship. "

The approximately thirty pages that composed each issue were enriched by many images, both drawings and photographs, almost in every sheet relating to the text of the articles. Apart from discussing ongoing war events, the various articles illustrated historical and mythological facts, customs and habits, theatrical genres, figurative arts, ongoing warfare, weapons and armour, iconography and religious architecture, clothing, landscapes, education, women occupations and more, all that could serve to make the lifestyle of the Asian ally more familiar. The sale price was, in fact, popular, three lire, less than two euros at the current revalued value. 


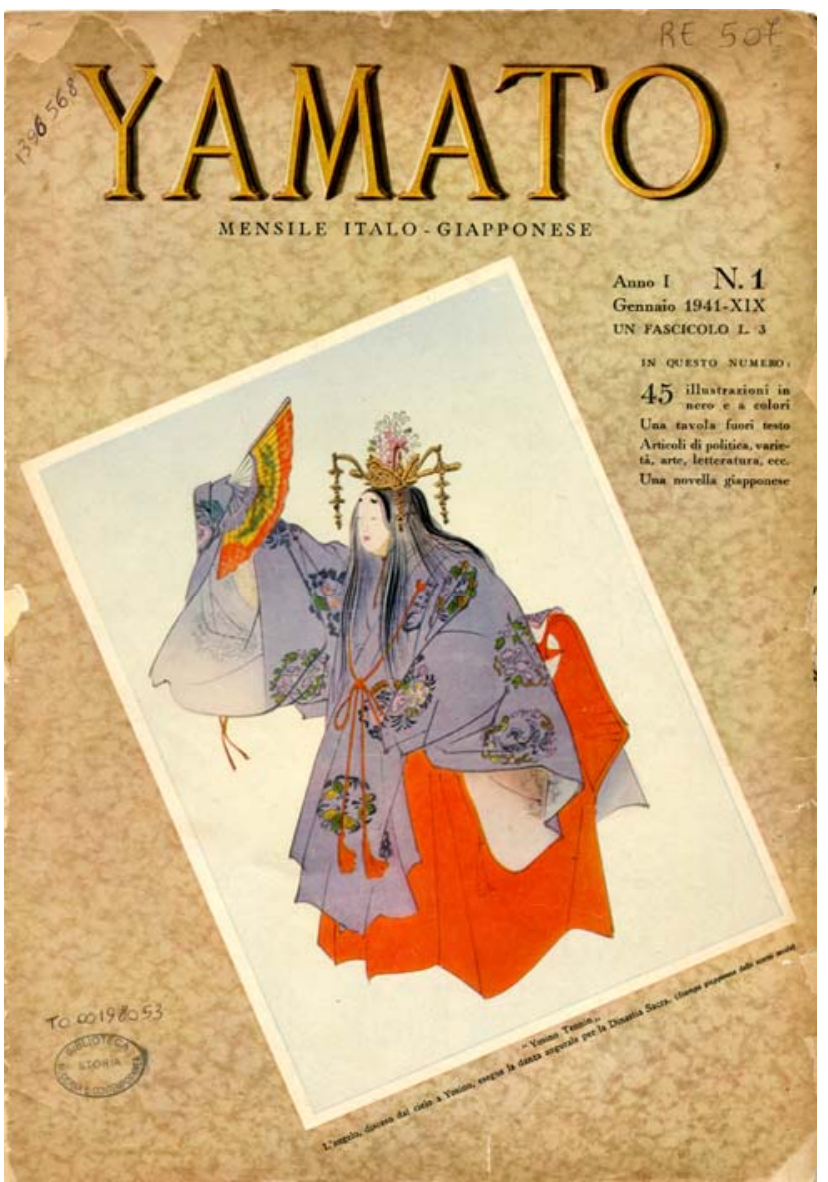

Picture 5. Yamato's cover, first number. Yamato. Mensile italo-giapponese, 1941, Jan., I(1)

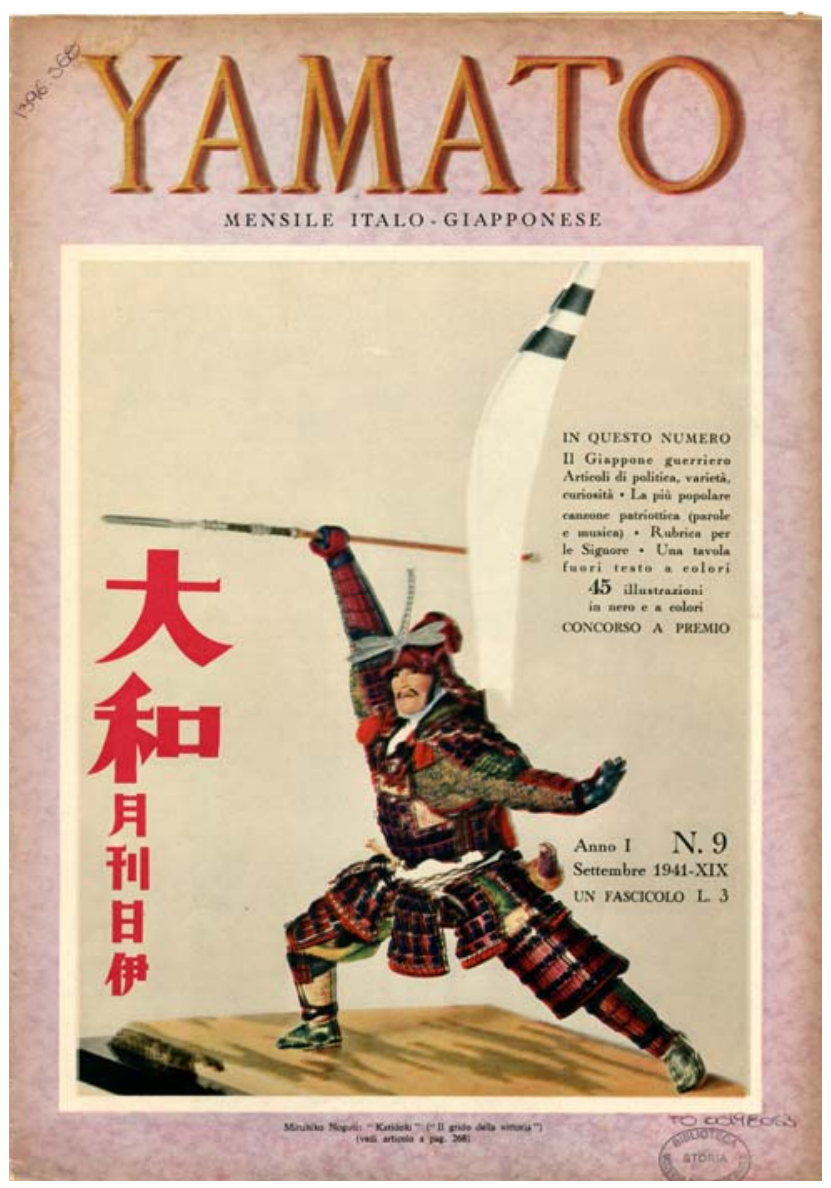

Picture 7. Samuarai, the cry of victory. Yamato. Mensile italo-giapponese, 1941, Sep., I(9)

\section{YAMATO}

MENSILE ITALO-GIAPPONESE

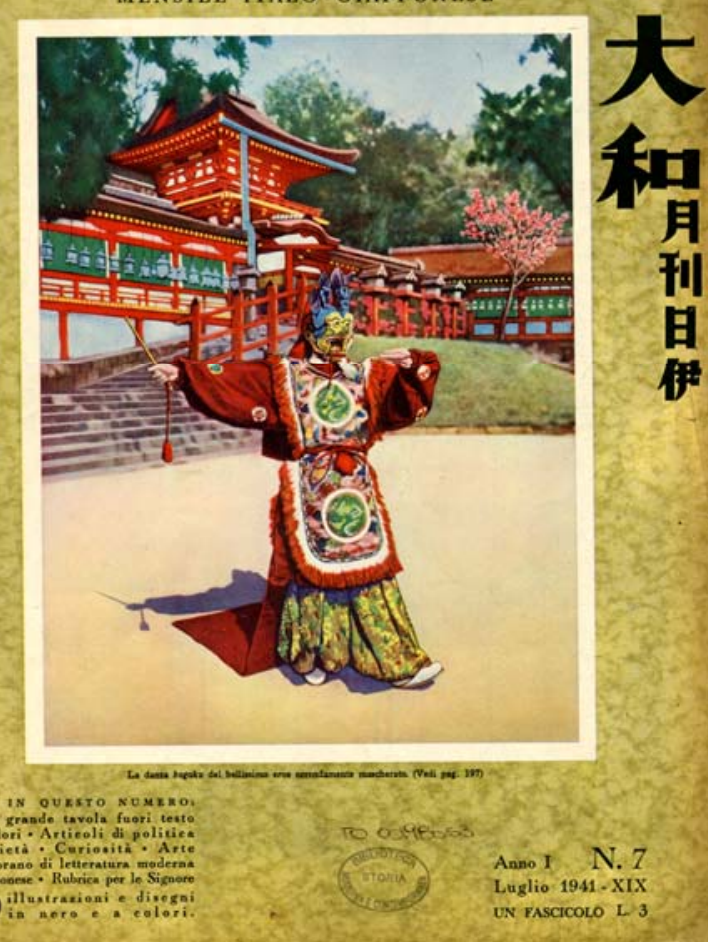

Picture 6. Traditional japanese dance. Yamato. Mensile italo-giapponese, 1941, Jul., I(7)

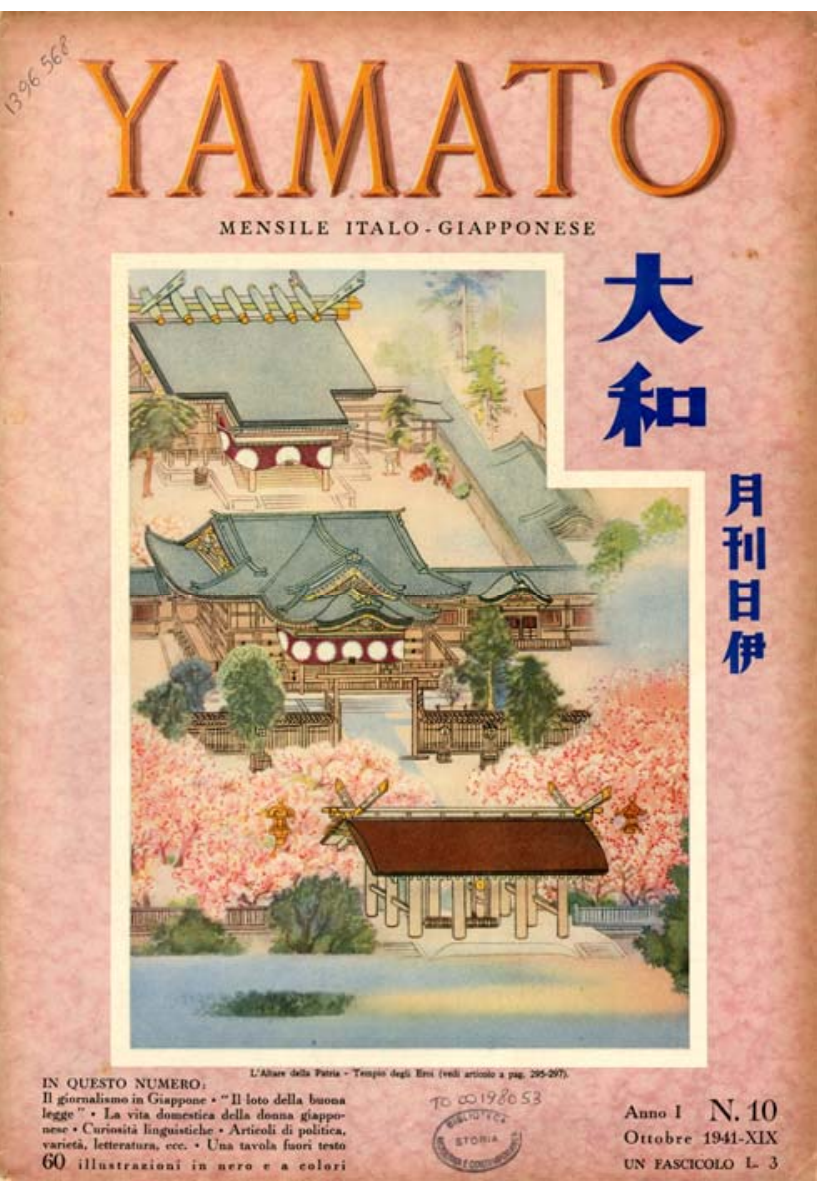

Picture 8. Temple of Heroes. Yamato. Mensile italogiapponese, 1941, Oct., I, I(10) 


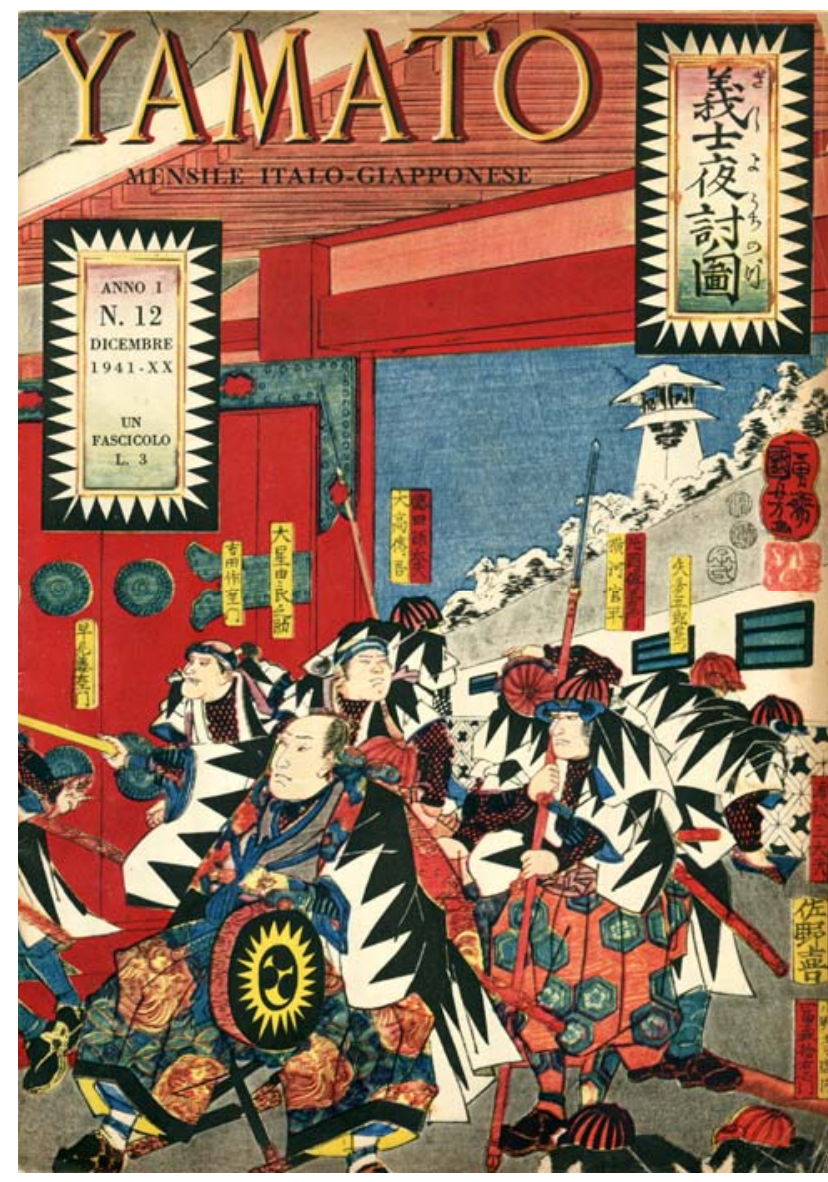

Picture 9. Samurai. Source: Yamato. Mensile italogiapponese, 1941, Dec., I(12)

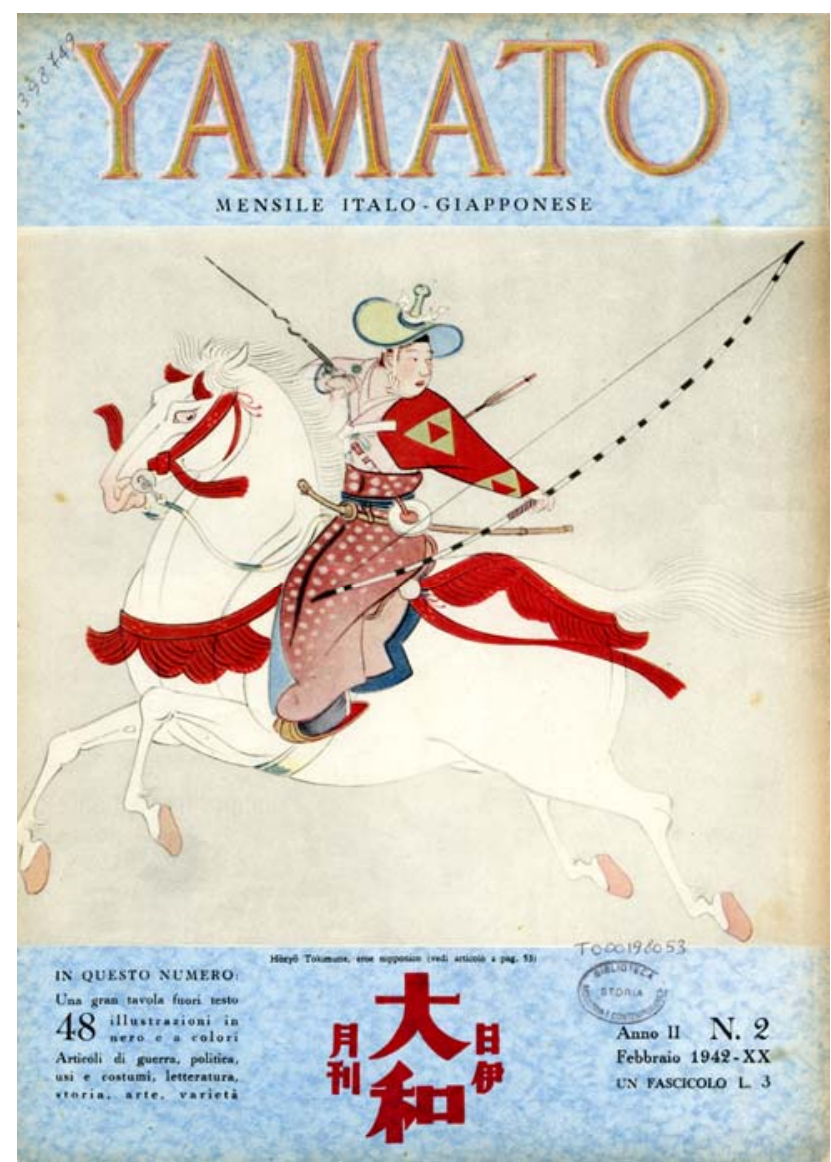

Picture 11. Shikken (regent Shogun) Hōzyō Tokimune. Yamato. Mensile italo-giapponese, 1942, Feb., II(2)

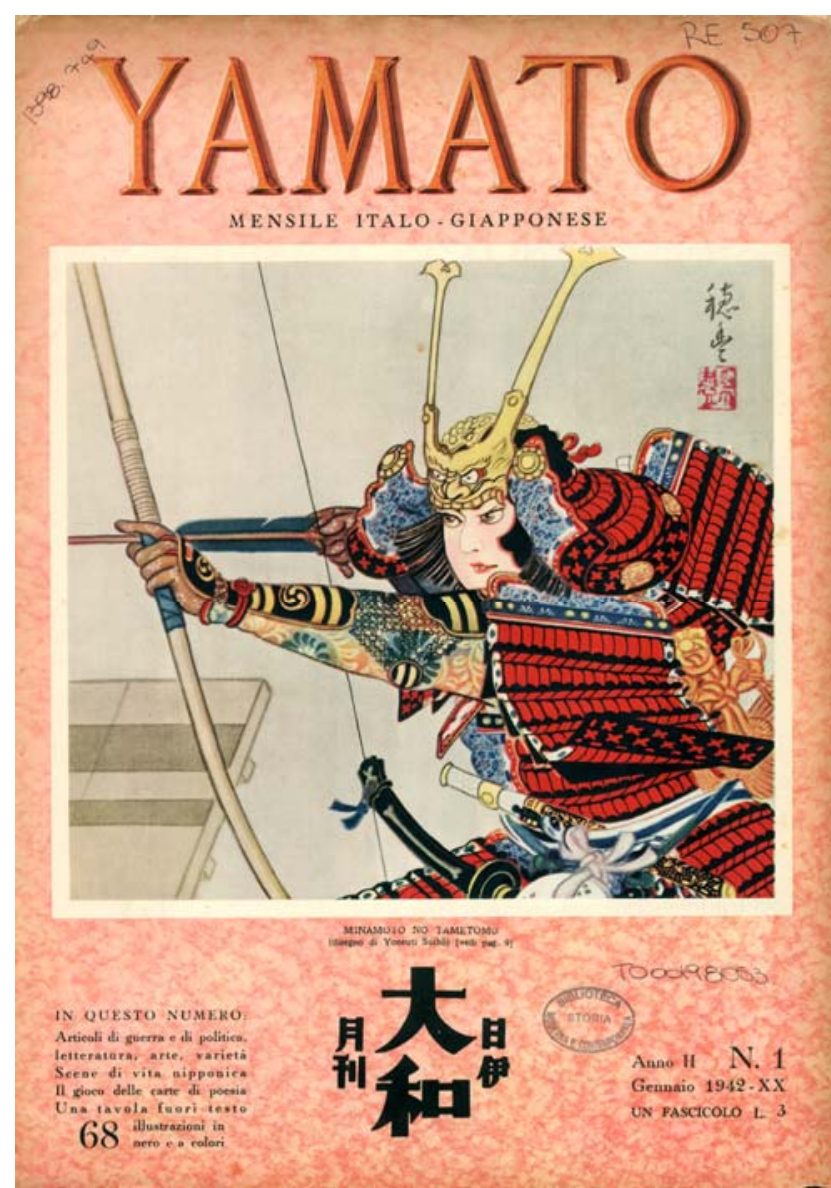

Picture 10. Samurai hero Minamoto no Tametomo. Yamato. Mensile italo-giapponese, 1942, Jan., II(1)

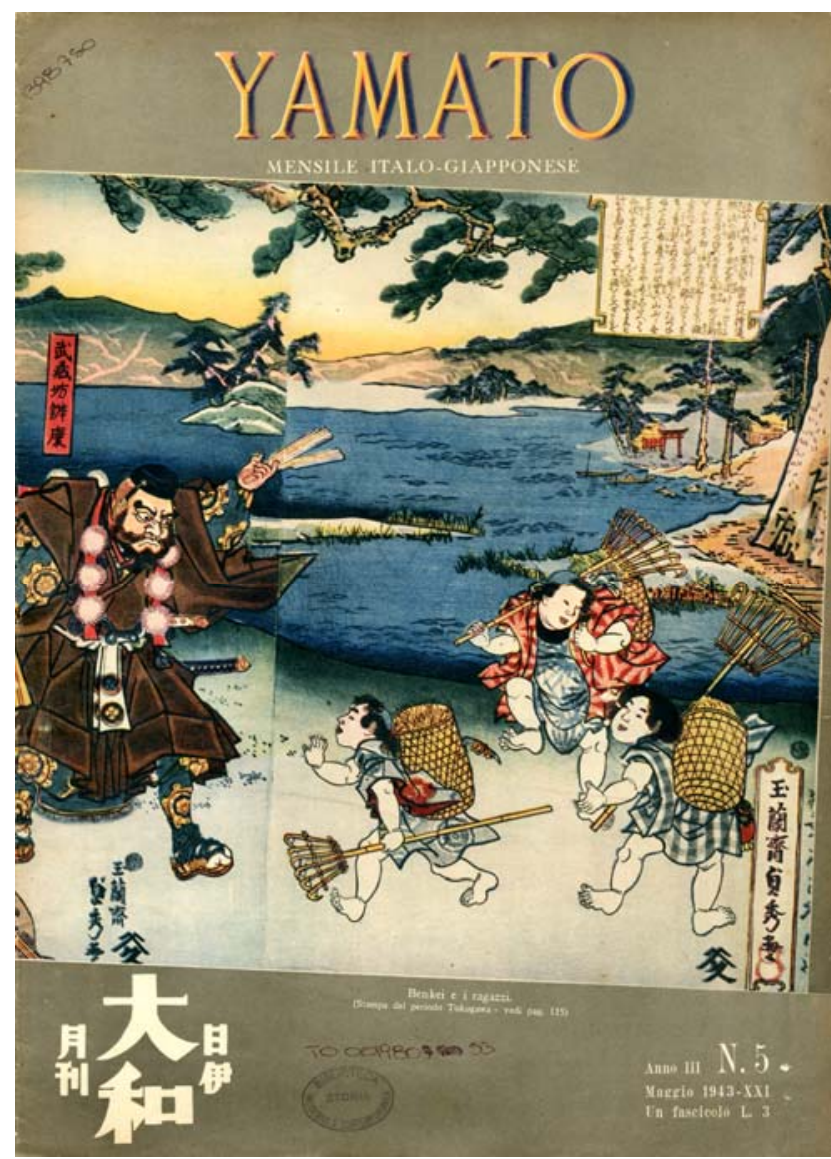

Picture 12. Legendary hero Benkei and the childrens. Yamato. Mensile italo-giapponese, 1943, May, III(5) 
Nevertheless, the authors never forgot the political message of the magazine, not only in the articles informing about the course of the war and the strategies of the other nations. In fact, there was a constant focus on communicating the concepts already expressed in the monographic number of "Sapere", with the use of a tenacious recall on the Japanese spirit of identity. Identity that can be traceable, ultimately, to bushido morality, according to the interpretation drawn in 1899 by Inazo Nitobe, but that was strongly reestablished in the home Country, especially from September 1937, when the same Japanese government planned a national congress to mobilize all Japanese people. This strategy was built to start an ideological homogenization with the purpose of stimulating popular support to the war, first of all against China (Benesch, 2014; Tipton, 2011). Actually, the Japanese people were little enthusiast about adhering to the war adventure in China just because, until the midthirties, they did not have a unique ideological setting (Havens, 1986, p. 12). During the following three years, the government orchestrated a widespread and severe Movement for Spiritual Activism coordinated

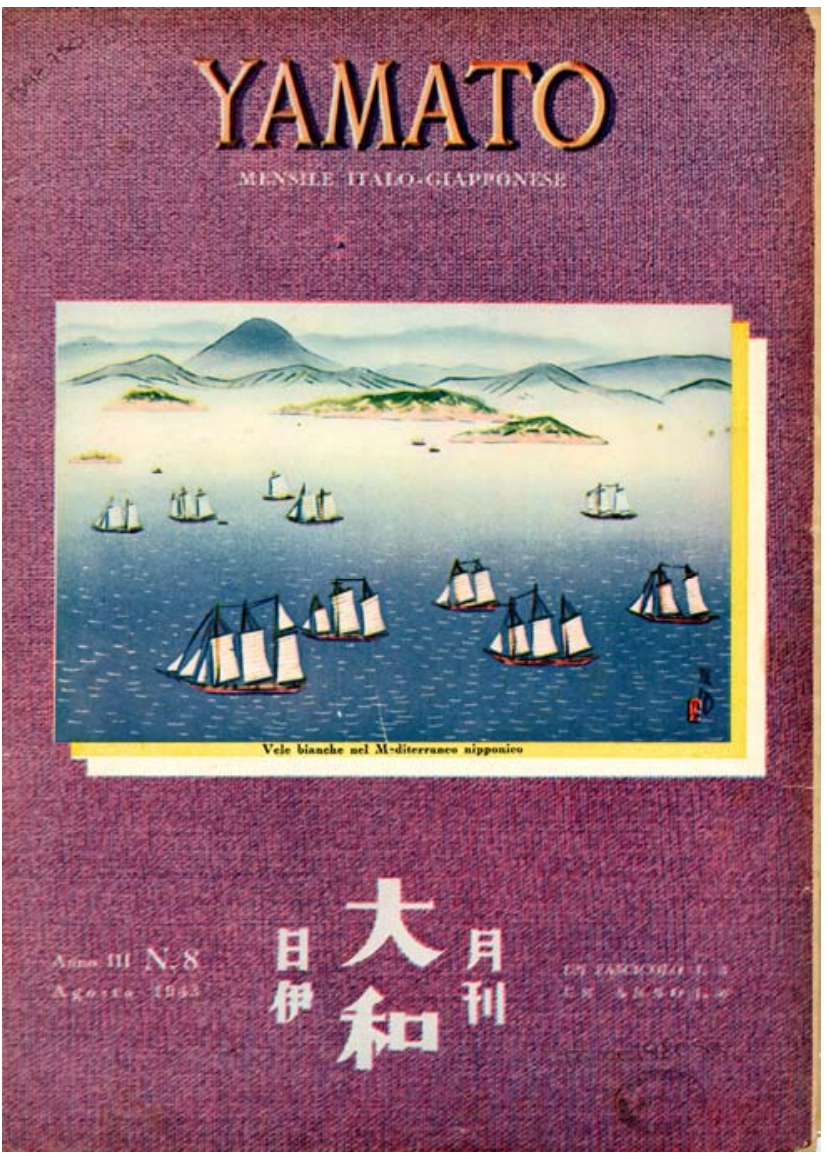

Picture 13. Yamato's cover, last number. Yamato. Mensile italo-giapponese, Aug., III(8) thanks to association of neighbourhood. These structures, besides promoting frugality instead of amusement, imposed discipline with pilgrimages to the imperial tombs, greetings to the soldiers and to the wounded ones, but also with lectures and meetings of judo and kendo. It is also true that the government used propaganda in favour of war as a mean of conquest; a mean that found fertile ground in the idea, very popular among the low classes, but also among intellectuals, of the Japanese being a dominant race (Benesch, 2014; Dower, 1986, p. 213).

The structure of the magazine Yamato, the other newspapers of the time that took place in Japan and the documentaries of the aforementioned Istituto Luce exactly replied to this nationalist and military activism prevailing in Japan. However, in order to make a proper selection among the many topics covered by the magazine, we can follow a chronological order to comment some extracts from the most significant articles for the use of political concepts of yamato damashi and, above all, the concept of bushido.

First of all, the presentation of the sports activities written by Nogami Soichi (1910-2001) is very emblematic (in the second issue of the magazine, though, appeared the Italian version of the name) (Soiti, 1941). The author was at that time studying at La Sapienza University in Rome with a studentship, and he was in charge of Kokusai Bunka Sinkokai, the International Organization for the Promotion of Culture, established in 1934 by the Japanese Ministries of Education and Foreign Affairs to promote cultural exchanges with foreign countries. "The Japanese, a healthy people, with an elastic body and an elastic mind, have been practicing sport for centuries, because they were and they are warriors, and practiced sport by manipulating weapons." "The original Japanese sports were and are assaulting fights." Even the same sports practiced in the rest of the world like skiing, soccer, skating , swimming, mountaineering, etc.," continued Nogami, "have in Japan an important connotation that makes them different ... The most important difference concerns ... the participation of the spirit. According to the Japanese conception - that is, according to the concept of the busidô [SIC!] or the spirit of the samurai - the purpose of sport is not the physical development of man, but the education of the soul through muscular exercise. This final intent is more evident in 
the traditional sport of kendô, that is the antique style of fencing, and in the zyûdô [SIC!], that is the typical Japanese struggle, the 'giùgìtsu' [SIC!]. To be skilled masters, fencers and excellent wrestlers, athletes must have a perfect moral character, because the technique has a secondary importance to that ... In short, Japanese sport ... is a healthy education of the soul rather than a discipline of the body: it can also be considered as part of those rites of worshipping the ancestors that pushes all the Japanese to keep themselves ready to fight against the enemy, to defend the Empire, under the leadership of the Emperor, the descendant of the uninterrupted dynasty that originated from the first Japanese Divinity, the goddess Amaterasu-ô-mikami." Also the captions of two of the images that accompanied the article are interesting. In a picture, a group of girls intent on exercises with the naginata - literally long sword, but called the samurai alabarda - under the guidance of a seventy-year-old lady, "expert in the military arts", for the development of muscle, intelligence and spirit. In another picture there are two girls in the act of launching an arrow with their bows, with the caption explaining how the archery was "important and serious because it coordinates and disciplines the body and soul and also prepares future mothers and future brides". The article, therefore, clearly considered martial arts and, in a more spiritual way, any other sport a useful exercise for the formation of its own social role, which was well defined and oriented to the defence of the Country's patriotism and national religion, or to fulfill the tasks of wife and mother. This was a thought which expressed a clear political vision, which was very distant from one of the two fundamental principles - "prosperity and mutual well-being". This vision was also very distant from the other main principle, which is "maximum efficiency with the least effort" - with which Kano Jigoro defined judo. It was also very different from the goals of leisure and sociality, as well as psycho-physical well-being, which for decades have animated the practice of modern sport around the world and in various social classes. It should be noted that such ideas were formulated by a prestigious intellectual such as Nogami Soichi, who created in 1951 the Italian Institute of Studies "Dante Alighieri" of Kyoto.

Shimazu Hisamoto (1891-1946) also wrote an article, which was very explicit, about the meaning of cherry blossom for the Japanese spirit. The author began by quoting an ancient saying: "Among all the flowers, the cherry; and among the men, the samurai". The article continued with tones sometimes even lyric but always functional to a clear political pedagogy oriented to the absolute respect of the social hierarchy and to the exaltation of war: "Among all the flowers, the most beautiful and most admired by the Japanese people is that of cherry trees (sakura). Thus, among the various social classes, the most respected and honored man is the samurai, the warrior, for his loyalty and his complete dedication to the Emperor and the Homeland. The samurai can rightly and perfectly represent the Japanese national spirit... sakura is the essence of... yamatodamasii, of the busidô. Samurais are the incarnation of the busidô through the teaching of cherry blossom ... The spirit of sacrifice is tenaciously affirmed by the busidô, then based on the sublime desire of 'dying for the Emperor' and on the noble awareness of 'descending from glorious ancestors' ... Honest conduct and faith, serene death for the glory of the Empire, absolute loyalty: here are the teachings that flowering cherry imparts when its petals fall to the ground without regret as soon as the right time is arrived ... The busidô has the requirements of peace and grace of which the cherry blossom is symbolic. The bushido commands the peaceful spirit, elegance, and cordiality among the duties of chivalry: it exhorts poetic feelings and love for human nature, while displeasing the roughness and dullness. The Japanese people have always the greatest respect for those who know they are both a valiant warrior and men of fine taste in art and poetry ... a young samurai is often qualified as 'a busi like a flower cherry' and his actions in war and his glorious death in combat are praised with a thought that resembles that similarity. Even with the enemy, the busidos requires that his end is made up of the same feeling that one must have towards a beautiful flower that dies under the storm... The flowery cherry shows the charm of a united crowd, how the nation is all around her Emperor ... I hope that you, Italian friends, will understand this floral message as the young warriors of our history understood it. I hope also that the example of flowered cherry will serve us all to incite us on the path of true progress" (Shimazu, 1941).

The Italian editors were eager to explain the repeated invasions of Japanese armies in the neighbouring continental areas by attributing to "Japan an absolute superiority to other East Asian countries, in terms of energy, of a high moral and intellectual level, of organizational and military power "(Politicus, 1941, an unnamed pseudonym that perhaps concealed Rivetti himself, despite 
the fact that he was already signing his articles as Toddi). They talked very much about the story of the 47 Rônin, discussing on how the story had become "for the Japanese nation the symbol of its feeling of honour" (Auriti, 1941).

The editors also underlined the political role of bushido with an article dedicated to the Japanese school system, with which they identified many points of contact with the fascist school organization (Nicastro del Lago, 1942). Among these points of contact there was a strong prevalence of male teachers, "and this was thought to give the students, from the very beginning, a 'male' education of their character, whose formation constitutes the essential goal of Japanese education ... and in that we can recognize a substantial parallelism with the principles of fascist reform. The purpose of the school is shaping loyal citizens, who are morally and physically strong, and who are animated by the most fervent patriotic feelings." The author also - not without mistakes in writing the words about martial arts - noted that "as in nowadays Italian school great importance is given to physical education and also, from the fifth year onwards, to military education: this includes, for males, the zyûdô, that typical Japanese fight system known in Europe under the anglicized name of jûjitsu, and the kendô, which is the traditional fencing of feudal times, still practiced in the ancient style. For females, however, the subject of teaching the art of battling with the alabarda (naginata). Such gymnastic and war-like teachings should serve not only as a physical training, but also as a development of the morality and chivalrous virtues of the busidô". These statements were reinforced by two black and white photographs showing a dozen students engaged in the kendô and about fifteen boys and girls, with a slight prevalence of the last ones, who practiced with naginata under the guidance of a lady.

In that same issue, another Italian pen signed an intervention that dealt more deeply with judo (Santoro, 1942). After focusing on the salient differences between this type of struggle and those of Western origin, including boxing, above all because the least possesses a "defensive character more than offensive, and teaches to reject than to attack," the author invited to not underestimate the "moral, political-social, sentimental and aesthetic value of this struggle". In fact, "this sport is considered to be an exercise of the soul rather than of the muscles, as a way of exercising and developing the moral qualities of the perfect 'samurai', that is the vir nipponico, and this was the same identification between samurai and authentic virility already seen in the cherry blossom."

In the issue of May 1942 appeared a direct contribution written by the intriguing Colonel Shimizu, which reproduced a conference in the association "Friends of Japan" with which the officer analysed the country's foreign policy in the ongoing war (Shimizu, 1942, May). Shimizu explained that many nations were still referring to Japan in an incorrectly way because of a too superficial knowledge, a way that was based only to certain customs or to industrial power; even the most noble tradition of the bushido, expressed by the samurai, was still considered a legacy of the past, without realizing how it was continuing to live in contemporary Japanese society. Colonel Shimizu then went on writing with tones of clear racism by defining the "personality of the Japanese people" completely different from the Chinese, Mongolian or other Asian people, according to European schemes. The Japanese people, Shimizu clarifies, is "the result of the union of so many races including the Aryan one - but with a history, tradition, spirit, development and progress other than the other races that formed it. It belongs to a race 'Yamato' unmistakable for many characteristic elements. Characteristics summed up in a temperament capable of expressing both feelings of deep sweetness in front of the spectacle of nature and of fierce determination in the pursuit of justice, resulting in fraternity and generosity regarding the first side, decision, sacrifice, love of justice for the second". Shimizu was thus launched into a plain affirmation that apparently tended not only to flaunt his audience but to express the essence of the cultural operation that animated the activities of the association "Friends of Japan": "All this, I think, is very close to the Roman conception of the fascist Italian people wanted by your great Duce."

A few months later "Yamato" reiterated how much Japan was considered an indispensable ally for the final victory of the war by Mussolini himself. On the front page of the issue of December 1942 was reported an extract from a recent speech made by the dictator, where English and American were slandered for their defeats in Asia, due to the fact that they "knew nothing of the military force of Japan and, above all, of its intimate moral strength, that is so big that in Japan the 
Emperor not only has the authority, but even the dignity of a god, and the soldiers who die in war are deified. It is really hard to beat a people who have in themselves moral resources of this nature" (Mussolini, 1942). This exaltation, however, did not save either Fascism or Mikado from a catastrophic moral, even more than material, defeat: one just has to think of the ban on the reconstitution of the fascist party contained in the Constitution of the Italian Republic and the conduct of Japanese troops in all the Asian countries invaded before and during the Second World War that caused such hostility that even nowadays is still felt (Tipton, 2011, pp. 217-227).

To conclude this selection of the "Yamato" publications, it seems particularly useful to talk about an article dealing with the tendencies of modern Japanese art. The essay shows, in fact, that the ideology guided the country to an overall adaptation of social structures, in order to make them develop progress equal to that of the other nations, while maintaining the traditional features of the Japanese spirit. The "Yamato" ideology pervaded every aspect of national life, including artistic production. Even more significant in the text is the choice of a particular painting that accompanies the article. The work is not dated but it is stated that its author was born in 1895, so it is likely to be placed somewhere during the thirties of the twentieth century. Its content is, however, very explicit in communicating the principles transmitted by the Movement for Spiritual Activism promoted by the government since 1937, beginning with the title, Heroic Program. The painting depicts Oda Nobunaga (1534-1582), the first to start a process of national unification, while he is observing a global map of the world, meditating on grandiose conquest projects that he partly managed to achieve. Really very significant is the presence on the sides of the leader of a black panther and an African young man sitting in front of what appears to be a piano, as if to indicate imperial goals far beyond Asian territories.

\subsection{The magazines: Civiltà}

After some examples of Yamato editorial production, we can conclude this essay examining two articles published in 1942 on the magazine Civiltà. This quarterly magazine accompanied the Universal Exhibition of Rome and both articles were written by famous people: the first one by Giovanni Gentile, was published in January and the second one by Giacinto Auriti, was published in July. Auriti told, once again and with lots of details and eloquent images, the story of 47 Rônin. He underlined the everlasting success of books and performances devoted to this story to reiterate that "it is still cited as one of the finest examples of faithful and heroic spirit of human race" (Auriti, 1942).

With respects to the contents repeatedly upheld by his Fascist intellectual colleagues, Giovanni Gentile took a completely different direction for his article. Although the title of the article was "Giappone guerriero" (Warrior Japan) (Gentile, 1942), the author explained the Japanese soul, which had quickly experienced a productive and institutional modernization without relinquishing its traditional spiritual structures, without referring to bushido concept, nor to yamato damashii or samurai ethics or to the symbolic cherry blossom. He otherwise referred to shinto concept, described as "family and country religion, since the whole country is a family gathered under the Emperor who, through the unbroken chain of the dynasty, binds all the Japanese people to the divinity from whom he directly descends". Gentile used this particular perspective to make a comparison between Japanese and Christian traditions: through a clear-headed but misleading reasoning, he arrived to political affinities with European powers engaged in fighting the "double danger of communism and industrial imperialism".

\section{Conclusions: Instead of Prometheus?}

Italian perception of Japan was very little related to the aesthetic fashion of late nineteenthcentury "Japonism", more significant in France, England and Germany (Arzeni, 1987; Buttò, 1996) except for the particular case of Gabriele D'Annunzio (1863-1938), to quote the most known one. However, examining Italian cultural production about Japan after 1905 Russian-Japanese War, we can see how this perception has been defined by the same features since then; features also typical of documentaries and periodicals published between late 30s and early 40s. In the perspective 
promoted first by Balbi and then by fascist intellectuals, bushido was the essence of Japanese identity for what concerns militarism and nationalism, to be taken as example by Fascist Italy to educate the masses to war.

All the sources analyzed in this essay, such as the 1938 footage of the Istituto Luce, the 1940 monographic dossier of Sapere magazine, the thirty-two Yamato numbers published between 1941 and 1943, the 1942 articles published on Civiltà magazine, were all about some basic concepts: the spirit that sublimates the matter with the consequent resetting of economic and political conflicts, all summed up in country ideals; the unshakeable and total loyalty of the individual to the hierarchy, both in family and society circles, following the example of 47 belligerent Rônin and of gentle Butterfly; surrender of individuality in favor of the collective; the extreme and mystical sense of duty as the fulfilment of the traditional moral ideal; the role of women as essentially domestic.

It is no surprise that Fascism was attracted by this conception of the world, nor that anti-modern Japanese orientations were attracted by fascism. However, it must be emphasized that fascist intellectuals found in bushido the concrete expression of this vision of the world and linked it to the unlimited spirit, expressed by the concept of yamato damashii. Japanese martial arts, thus constituted a very effective platform on a symbolic level to support the alliance policy between the totalitarian powers of Italy and Japan, both engaged in imperialistic assault operations. This clear political function would have failed with the fall of fascism, but its effects on the imaginary would have remained. At least until 1970s, mass perception of Japanese martial arts would have been of a possible Fascist legacy, a perception shared by both the critics and those who appreciated it for this very reason (Raimondo, 2008). Otherwise some symbolic stereotypes would have remained part of the popular culture even in the following decades (Nolitta, Bignotti, \& Ferri, 1980, April, May).

Italian public opinion perception of Japan's identity adhered to the idea - especially

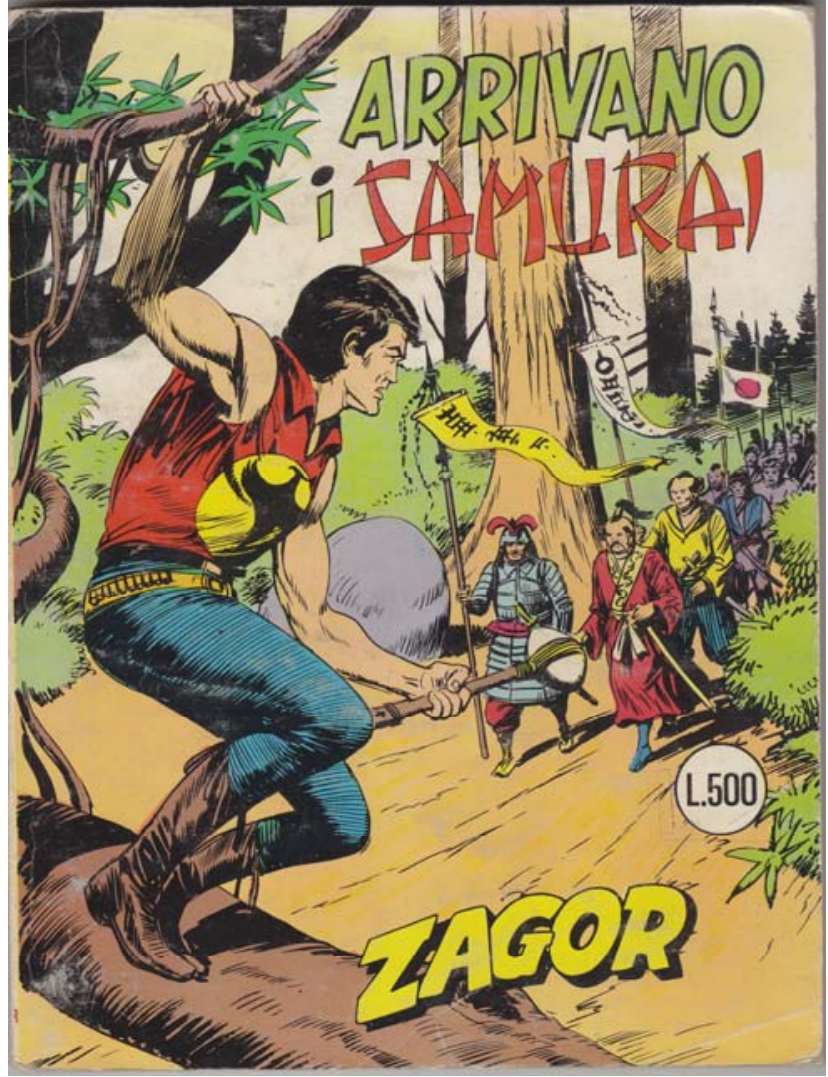

Picture 13. Arrivano i Samurai. Source: "Zagor", 1980, April, 117.

supported by Auriti, Rivetta, and Tucci -according to which Japan had been able to implement its modernization without sacrificing its traditional anthropology, identifiable with the bushido code. An approach that would probably undermine the classic approach of David S. Landes (1924-2013) (Landes, 1969): bushido instead of Prometheus, we might dare to say...

\section{Acknowledgments}

I am debtor to prof. Doi Hideyuki, Ritsumeikan University of Kyoto, of the biography of Moriakira Shimizu, as well as several other useful comments made in numerous talks. Thank you to Federico Ciancarella who scanned the pictures for this paper at the Modern and Contemporary History Library of Rome.

\section{References}

Aloisi, P. (1941, May). L’eroico episodio delle "Tigri Bianche”. Yamato. Mensile italo-giapponese, a.I, n.5, pp. 137-138. 
Arzeni. F. (1987). L'immagine e il segno. Il giapponismo nella cultura europea tra Ottocento e Novecento. Bologna: Il Mulino.

Auriti, G. (1941, December). La storia dei quarantasette "rōnin" e il "seppucú". Yamato. Mensile italo-giapponese, a.I, n.12, pp. 367-369

Auriti, G. (1942, July 21). I quarantasette "Rônin". Civiltà. Rivista trimestrale dell'Esposizione Universale di Roma, a.III, n.10, pp. 85-88.

Avarna di Gualtieri, C. (1940). La politica giapponese del "Nuovo Ordine". Milano-Messina, Principato.

Avarna di Gualtieri, C., \& Società Amici del Giappone (1940). Roma Berlino Tokyo: numero unico dedicato alla conclusione del patto di alleanza tripartito. Roma: Tip. Poliglotta.

Balbi, B. (1916a). Come il Giappone prepara le vittorie?. Napoli: Casa editrice Italo-cino giapponese Iwakan Hakkosha.

Balbi, B. (1916b). I canti dei fiori e I canti delle spade. Napoli: Casa editrice Italo-cino giapponese Iwakan Hakkosha.

Balbi, B. (1916c). La psiche e la virtù bellica del popolo giapponese:Yamato-damashii. Napoli: Casa editrice Italo-cino giapponese Iwakan Hakkosha.

Beasley, W.G. (1969). Storia del Giappone moderno. Torino: Einaudi. (Original edition, The Modern History of Japan, Weidenfeld and Nicolson, London, 1963).

Benesch, 0. (2014). Inventing the Way of the Samurai. Nationalism, Internationalism, and Bushido in Modern Japan. Oxford: Oxford University Press.

Bernardini Napoletano, F. (Ed.). (2015). Ungaretti. Da una lastra di deserto. Lettere dal fronte a Gherardo Marone. Milano: Mondadori.

Boari, E. (1908). Racconti del vecchio Giappone. Milano: Sonzogno.

Buttò, S. (1996). Il Giappone svelato: la "provincia" italiana e una moda europea. In Biblioteca Nazionale Centrale Vittorio Emanuele II, Pagine dall'Oriente. Libri cinesi e giapponesi della Biblioteca Nazionale (pp. 47-74). Roma: Bardi.

Calanca, D. (2016). Bianco e nero. L'Istituto Nazionale Luce e l'immaginario del fascismo (1924-1940). Bologna: Bononia University Press.

Calvitt Clarke, J. (1999). Japan and Italy squabble over Ethiopia: the Sugimura affair of July 1935. In Selected Annual Proceedings of the Florida Conference of Historians, 6, 9-20.

Caroli, R., \& Gatti, F. (2004). Storia del Giappone. Roma-Bari: Laterza.

Centro studi Giacomo Puccini. (2005). Madama Butterfly, fonti e documenti della genesi. Lucca: Maria Pacini Fazzi.

Conti di Verampio, E. (1946). Dal taccuino di un borghese. Il Mulino: Milano.

Degli Uberti, U. (1933). Nei mari dell'Estremo Oriente. La guerra navale russo-giapponese 1904-1905. Milano: Corbaccio dall'Oglio.

Del Boca, A. (2007). I gas di Mussolini. Il fascismo e la guerra d'Etiopia. Roma: Editori Riuniti.

Doi, H. (2014). Harukichi Shimoi e l'avanguardia napoletana. In M.K. Gesuato (Ed.), Ricerca, scoperta, innovazione: l'Italia dei saperi (pp. 43-51). Tokyo: Istituto Italiano di Cultura.

Dower, J. (1986). War Without Mercy: Race and Power in the Pacific War. London-Boston: Faber \& Faber.

Fatica, M. (2014). The beginning and the end of the idyllic relations between Mussolini's Italy and Chang Kai-Shek's China (1930-1937). In M. Marinelli, \& G. Andornino, G. (Eds.), Italy's encounters with modern China - imperial dreams, strategic ambitions (pp. 89-115). New York: Palgrave Macmillan.

Ferretti, V. (1986). Politica e cultura origini e attività dell'Ismeo durante il regime fascista. Storia contemporanea, XVII(5), 779-819.

Ferretti, V. (1995). Il Giappone e la politica estera italiana 1935-41. Milano: Giuffrè.

Formichi, C. (1942). Giappone: volume dedicato all'amicizia italo-giapponese. Bologna: Margotti.

Garzilli, E. (2012). L'esploratore del Duce. Le avventure di Giuseppe Tucci e la politica italiana in Oriente da Mussolini a Andreotti. Con il carteggio di Giulio Andreotti (vol.I). Milano: Asiatica Association.

Gentile, G. (1942, January 21). Giappone guerriero. Civiltà. Rivista trimestrale dell'Esposizione Universale di Roma, a.III, n.8, pp. 5-12.

Giro, M. (1986). L'Istituto per l'Oriente dalla fondazione alla seconda guerra mondiale, Storia contemporanea, XVII(5), 1139-1176. 
Havens, T. (1986). Valley of Darkness: The Japanese People and World War Two. Lanham, Maryland: University Press of America.

Hofmann, R. (2015). The Fascist Effect: Japan and Italy, 1915-1952. Ithaca: Cornell University Press.

Illica, L., Giacosa, G., \& Puccini, G. (1904). Madama Butterfly (da John Long e David Belasco). Tragedia giapponese. Milano: Ricordi.

Istituto Nazionale Luce (1938a, April 27), La missione studentesca giapponese [video], "Giornale Luce B1295", Senato della Repubblica - Archivio Luce.

Istituto Nazionale Luce (1938b, August 3), La missione economica italiana [video], "Giornale Luce B1350", Senato della Repubblica - Archivio Luce.

Kanno, K. (trad. Doi Hideyuki). (December 2005). Che cos'è il bushidô. Cultura Italo-Giapponese, 2, 9-21.

Lanciotti, L. (1962). La donazione Auriti al Museo Nazionale d'Arte Orientale, Il Giappone, 2(3), 3335.

Landes, D.S. (1969). The Unbound Prometheus. Technological Change and Industrial Development in Western Europe from 1750 to the Present. Cambridge: Cambridge University Press.

Martinelli, L. (2003, May 18). La colonna del duce per i samurai. Il Sole24ore Domenica, n.135, p. 28.

Merlino, F.V. (2003). Il sodalizio Shimoi-D’Annunzio. In A. Tamburello (Ed), Italia-Giappone 450 anni. Roma - Napoli: Istituto italiano per l'Africa e l'Oriente - Università degli studi di Napoli L'Orientale.

Missione del Partito Nazionale Fascista nel Giappone [video] (1938). Retrieved from https://www.youtube.com/watch?v=q27NheMoVXQ.

Mitford, A.B. (trans. B. Balbi). (1916). I racconti del vecchio Giappone. I quarantasette ronin. Napoli: Casa editrice Italo-cino giapponese Iwakan Hakkosha.

Mussolini, B. (1935). Estremo Oriente. I Popolo d'Italia, XII, 18 gennaio.

Mussolini, B. (December 1942). Dallo storico discorso del Duce alla Camera dei Fasci e delle Corporazioni il 2 dicembre 1942-XXI. Yamato. Mensile italo-giapponese, a.II, n.12, p. 285.

Nicastro del Lago (1942, January). La Scuola Nazionale giapponese e la nostra Carta della Scuola. Yamato. Mensile italo-giapponese, a.II, n.1, pp. 22-3.

Nimura, J.P. (2015). Daughters of the Samurai: A Journey from East to West and Back. New York: W. W. Norton \& Company.

Nitobe, I. (trans. B. Balbi). (1917). Bushido: l'anima del Giappone. Napoli: Casa editrice Italo-cino giapponese Iwakan Hakkosha.

Nolitta G., Bignotti F., \& Ferri G. (1980, April). Arrivano i Samurai. Zagor, n.117.

Nolitta G., Bignotti F., \& Ferri G. (1980, May). La scure e la sciabola. Zagor, n.118.

Orsi, M.T. (2012). La storia di Genji. Torino: Einaudi.

Paulucci di Calboli Barone Russo, G. (1940, December 15). Amicizia italo giapponese. Sapere. Quindicinale illustrato di divulgazione delle scienze, della tecnica, delle arti e della cultura generale, a.VI, vol.XII, s.II, n.23/143, p. 319.

Pinguet, M. (1984). La mort volontaire au Japon. Paris: Gallimard. (Ed. it., M. Pinguet, La morte volontaria in Giappone, Garzanti, Milano, 1985).

Politicus (1941, June). Che cosa vuole l'America. Che cosa vuole il Giappone. Yamato. Mensile italogiapponese, a.I, n.6, p. 166.

Puette, W.J. (1983). The Tale of Genji: A Reader's Guide. Tuttle: North Clarendon VT.

Quadrivio. Grande settimanale letterario illustrato di Roma. (1935, 28 July), Il Giappone, 39, p. 8.

Raimondo, S. (2008). Martial arts and civil society in Italy during Sixties and Seventies. IDOMovement for Culture, 8, 38-44.

Ricordi, G. (1904). Rosina Storchio nell'opera di Madama Butterfly. Musica e musicisti, 59(5), 189192.

Sakurai, T. (trans. B. Balbi). (1913). Nikudan: proiettili umani. Episodi dal vero dell'assedio di Port Arthur. Tokyo-Grottaferrata: Sekai Koron-Tipografia Italo Orientale.

Santoro, G. (1942, January). La lotta giapponese "Arte gentile". Spirito del "Zyūdō". Yamato. Mensile italo-giapponese, a.II, n.1, pp. 202-3.

Sapere. Quindicinale illustrato di divulgazione delle scienze, della tecnica, delle arti e della cultura generale. (1940, December 15), a.VI, vol.XII, s.II, n.23, p. 143.

Shimazu, H. (1941, April). Il "sakura" e lo spirito nipponico. Yamato. Mensile italo-giapponese, a.I n.4, pp. 104-105. 
Shimizu, M. (1942, May). Quo vadis Nippon?. Yamato. Mensile italo-giapponese, a.II, n.5, pp. 118-119. Shimoi, H. (1919). La guerra italiana, impressioni di un giapponese. Napoli: Libreria della Diana.

Sica, M., \& Verde, A. (1999). Breve storia dei rapporti culturali italo-giapponesi e dell'Istituto italiano di cultura di Tokyo. Ravenna: Longo.

Soiti (Soichi), N. (1941, February). Febbraio sportivo. Yamato. Mensile italo-giapponese, a.I, n.2, pp. 58-59.

Tama Temple. (2017). Sumiaki Shimizu. Retrieved from http://www6.plala.or.jp/guti/cemetery/PERSON/S/shimizu mo.html

Teatro dell'Opera di Roma-Ufficio Stampa. (1990). Madama Butterfly. Roma: Edizioni del Teatro dell'Opera.

The Osaka Mainichi (1938, June 14). In Commemoration of Italian Economic Mission's Visit to Japan. The Osaka Mainichi \& The Tokyo Nichi Nichi (Special Supplement).

Tipton, E. (2011). Il Giappone moderno. Storia politica e sociale. Torino: Einaudi. (Original edition, Modern Japan. A social and political history, Routledge, Oxford 2008).

Tucci, G. (1942). Il buscidô. Firenze: Le Monnier.

Tucci, G. (1943). Il Giappone. Tradizione storica e tradizione artistica. Milano: Bocca.

Vlastos, S. (Ed.). (1998). Mirror of Modernity: Invented Traditions of Modern Japan. Berkeley - Los Angeles - London: University of California.

Zagra, G. (1996). Suggestioni dal Giappone nel panorama letterario italiano tra ' 800 e '900. In Biblioteca Nazionale Centrale Vittorio Emanuele II, Pagine dall'Oriente. Libri cinesi $e$ giapponesi della Biblioteca Nazionale (pp. 75-96). Roma: Bardi.

Zischka, A. (1935). Il Giappone nel mondo. L'espansione nipponica dal 1854 al 1934. Firenze: Sansoni.

\section{Author's biographical data}

Sergio Raimondo (Rome, Italy, 1959), Phd in Economic History. Master of Chen Taijiquan and Qigong. Fifth Duan Chinese Wushu Association, XX Chen Style Taijiquan generation as student and disciple of Great Master Chen Xiaowang, XIX generation, official world representative of Chen family. Currently: librarian at Biblioteca di Storia Moderna e Contemporanea (Rome, Italy); public and private teacher of Chen Taijiquan and Qigong; adjunct professor of Discipline Orientali dell'Autopercezione (Eastern Disciplines of Self-perception) at University of Cassino and South Lazio; adjunct professor of Taijiquan and Qigong at First level Master of Medicina Integrata (Integrated Medicine), University of Siena; member of Executive Board of International Martial Arts and Combat Sports Scientific Society; member of Scientific Committee of Revista de Artes Marciales Asiaticas and Ido. Movement for Culture; director of Scientific Committee of Discipline Orientali branch of Unione Italiana SPort per tutti (UISP). Email: sergio.raimondo@unicas.it ; sergio.raimondo@uisp.it

Valentina de Fortuna (Rome, Italy). Graduated in Interpreting and Translation at UNINT University of Rome and actively speaking English, French, Spanish and Chinese. Karate Shotokan former athlete. Currently employed as Foreign Exchange Clerk at Fiumicino International Airport in Rome and Freelance Translator. Email: vale.defortuna@gmail.com

Giulia Ceccarelli (Rome, Italy). Graduated in Interpreting and Translation at UNINT University of Rome, with a good knowledge of English, Chinese, French and Spanish languages. Former student of Taijiquan, following the teachings of $\mathrm{M}^{\circ}$ Sergio Raimondo. Currently employed as Chinese speaking Personal Shopper for ADR (Aeroporti Di Roma) S.p.a. at Rome International Airport, she is also a freelance translator. Email: giuliaceccarelli@iol.it 